\title{
KAKRŠENKOLI FILM DELAŠ, GA PRAVZAPRAV DELAŠ O SEBI Pogovor s Heleno Koder
}

Dan je bil lep, zgodnje jesenski. Skozi okna je lila tista prav posebna dopoldanska, malce porumenela, malce ščemeča svetloba, a zdelo se je, da ni zmotila nikogar. Nasprotno! V polni dvorani kina Kinodvor je starejše občinstvo Srečanj ob kavi posedlo po z zelenim usnjem prevlečenih stolih. Pozorno je spremljalo pogovor, ki ga je z Ines Tanović, bosansko režiserko filma Naše vsakdanje življenje, vodila scenaristka in režiserka dokumentarnih filmov Helena Koder. Po zaključku srečanja mi je naklonila čas in mirno pozornost.

Gospa Koder, spoznala sem vas, vi se tega ne morete spomniti, še v svoji mladosti, ko sem $\mathrm{z}$ vami in televizijsko ekipo potovala v Portorož na prvi filmski festival. Prav lahko bi začeli pogovor o tistih časih, lahko bi upoštevali zaporedje vnaprej pripravljenih vprašanj. Zaporedje, kakršnega ste tudi sami upoštevali v svojih nepozabnih dokumentarnih filmih. Toda ne, raje se prosto pogovarjajva o vas, morda tudi o življenju in ljudeh, nastajanju filma.

O nastajanju filma. Naj začnem, naj povem, da je delati film privilegij. Privilegiran si zaradi odnosa do dela, ki ga lahko živiš, doživiš. Film je umetnost, ki omogoči, da slediš svojim hotenjem. Vsi umetniki nekaj želijo, hočejo, imajo ambicijo, da se izrazijo.

V vseh vaših občutljivih in kultiviranih filmih, ki govorijo o literarnih in drugih ustvarjalcih ali o življenju v posameznih družbenih trenutkih in skupnostih, so vaša hotenja, tako se mi zdi, resnično našla svoj izraz. Dokumentarni film Vojna in pogajanja (1995) pa je drugačen. Je manj poetično dokumentaren, kot se zdijo drugi vaši filmi.

Mogoče, a jaz sem ta film delala z veseljem. Poiskala sem literaturo, se učila o tem, kaj pravzaprav pomeni pogajati se. In spoznala sem, da je pogajanje zapleten proces, ki ga je treba voditi, imeti pred seboj jasne cilje in predvsem je treba proces privesti do konca. Film je nastal po razpadu Jugoslavije in mislila sem, da je prav, da ta čas in pogajanja za Slovenijo, okrog česar je bilo veliko špekulacij, dokumentiram na najbolj avtentičen način, da se dokopljem do tiste globlje resnice za arhivskimi posnetki. Pri dokumentarnem filmu je avtentičnost pomembna, četudi - o tem ni dvoma - ostane tudi veliko zamolčanega. Dokumentarni filmi imajo svojo naravo, veliko ciljev naj bi dosegli, a sporočati 
morajo resnico, vsaj eno resnično resnico, avtorjevo. Kakršenkoli film delaš, ga pravzaprav delaš o sebi, pravim. Aktivistični filmi, ki so tudi dokumentarni, kot so denimo filmi Michaela Moora, pa mi niso blizu, čeprav jih rada gledam.

Si mislim, da je tako. Nič nasilnega ni v vas. Nasprotno, le spoštljivost do drugih in sveta in tolerantnost, zavzetost. Vse to je čutiti tudi v vsakem od vaših filmov.

Pomembno je, da film deluje, da so prizori organski del celote in da je tema dokumentarnega filma zanimiva. A naj bo še tako zanimiva, paziti moraš, da se ne vsiljuješ, da ne prestopiš meja, ki jih v svoji intimnosti ima drug človek, četudi imaš vsa njegova pooblastila; da ne vsiljuješ dogajanja, da opazuješ, da zaznano prepleteš s svojo naravo. Nenehno se je treba prilagajati s kamero. Vsak človek je svet zase.

Je to spoznanje tudi sicer vplivalo na vaše življenje in odnose?

Je, saj sem postala veliko bolj razumevajoča, tolerantna. Bolje sem začela razumevati ljudi. Dokumentarni film ti veliko vrne.

Rekli ste, maloprej, »prepleteš s svojo naravo«. Rekli ste tudi, da »zmanipuliraš« zaznano, spoznano tako, da je sporočilno in doseže cilj. Pripovedujete o ustvarjanju dokumentarnega filma, meni pa se po glavi mota analogija z delom »učitelja odraslih, tistega, ki ustvari izobraževalni program, ga vodi, pri tem pa poskuša doseči, da se študent zave znanja, ki ga nosi v sebi, in ga tudi izrazi. Učitelj v ta namen daruje vse svoje »sekundarno znanje«, ki si ga je nabral skozi svoje življenje, tako kot ste vi v svoje filme, scenarije in režijo vnesli svoje raznorodno znanje, svojo kulturo in emocije, da bi dosegli gledalčevo dušo in razum.

Ja, jaz nikoli nisem postavljala meja, nisem tak človek. Nikoli nisem ločevala prostora od časa, dela od življenja, prijateljev od sodelavcev. Morda ni bilo zmeraj najbolj prav ... S sodelavci smo zvečine postali prijatelji.

Želela sem se pogovarjati z vami, da bi izvedela, kako se steše filmski ustvarjalec iz nekoga, ki ni formalno študiral dramaturgije, scenaristike, montaže in podobno. Kako ste vi našli svoje poslanstvo? So to naključja, intuicija, instinkt?

Že v gimnaziji sem sodelovala pri snemanju nekega koprodukcijskega francoskega filma. Zgodaj sem zagledala kamero. Potem sem sodelovala v ekipi, ki je snemala film Kala. Študirala sem francoščino in italijanščino in se še kot študentka prijavila na avdicijo za televizijsko napovedovalko - tako so temu rekli takrat - in bila sprejeta. Potem pa, ko ste enkrat v vrtincu, ko vas »mašinerija « sprejme vase, se odpirajo priložnosti. To je drugače kot v drugih poklicih. Pri učiteljih ali zdravnikih je drugače, tam so stvari in poti bolj 
zakoličene. Na RTV so mi ponudili tudi skromno štipendijo, ki sem jo morala kasneje, če se prav spominjam, odslužiti s preprostimi administrativnimi deli. So mi pa obljubili, da bom lahko vodila kakšne pogovore. Medtem se je enostopenjski študij francoskega jezika, ki so ga vodili kar v francoskem oddelku NUK-a, spremenil v dvostopenjskega in meni se je zdelo, da bo najbolje, da grem znova v prvi letnik in se vsega pošteno naučim. Zelo sem si želela, da bi me po diplomi sprejeli v prevajalski oddelek RTV, a potreba po italijanskem in francoskem jeziku je bila manjša kot po nemščini ali angleščini. No, v tistem času so v naših kinematografih vrteli tudi dokumentarne predfilme, filmske novice, imenovane Filmske novosti. Bile so propagandne, kot so lahko odprto ali zakrito propagandni dokumentarni filmi. A poročale so tudi o dosežkih v znanosti, etnologiji, denimo. Nedvomno so name naredile vtis. Vedela sem namreč, da si ne želim delati takšnih filmov.

\section{Tudi negativno znanje ima svoj pomen?}

Ima. Pa so mi kmalu zaupali neko kontaktno oddajo. Zelo zagnano sem se lotila te naloge. In sem naredila »kažin «. Drugačna je bila tema, drugačna je bila dinamika te oddaje, šli smo na teren. Dobra je bila. Potem so me poslali v Monte Carlo, kjer so se znašle televizijske »vedettes «, zvezde malega ekrana. No, jaz sem bila določena za zvezdo naših televizijskih zaslonov, četudi zvezd takrat nismo poznali. In zdi se mi, da je prav v Monte Carlu nastal prelom. Namreč, tam sem najprej gledala filme kot Bonnie in Clyde, ki so na naše zaslone prišli šele več let kasneje. Predvsem pa sem videla dokumentarec BBC-ja, ki je spremljal obolelega moškega z rakavim tumorjem od diagnoze do odločitve za operacijo. Njega in njegovo družino. In takrat sem si rekla: Takšne filme bi rada delala. Od takrat dalje sem nosila v sebi vzor.

Če povzamem, želeli ste si, da bi filmi pri gledalcu ustvarili neko mentalno atmosfero, da bi bili avtentični, pošteni, informativni, da bi prenašali znanje, da bi bili koristni ljudem, kot ta dokumentarec. Če prav pomislim, sem ta vaš vzor prepoznala tudi v vaših filmih s prelepimi naslovi Mož brez posebnosti - portret Janeza Gradišnika (2000), Prizori iz življenja pri Hlebanjevih (1997), Kocbek, pesnik v pogrezu zgodovine (2004), Magdalenice gospe Radojke Vrančič ( 1997) in drugih. Lahko malce postaneva pri magdalenicah, »žlebičastih kot školjke pokrivače«, kot je zapisala naša velika prevajalka Marcela Prousta?

Magdalenice gospe Radojke Vrančič je zgrajen, domišljen film. Vnaprej domišljen s trdnim scenarijem. Film, ki smo ga snemali v okolju urbane vile, z gospo Vrančič, ki izhaja iz meščanske, uradniške družine z vrednotami svojega družbenega sloja, načinom življenja, prepoznavnim literarnim in drugim okusom. Sicer pa poklic književne prevajalke ni prav nič fotogeničen. Pisalni stroj ali računalnik, knjige in delo. Drugače bi bilo snemati film o slikarju ali filmskem igralcu. Tam bi bilo kaj videti. Tu pa ... Vendar preplesti Prousta, njegovo besedilo, s pripovedjo prevajalke gospe Radojke Vrančič, njegov odnos do časa, njegov psihološki čas, v katerega prikliče podobe iz podzavesti, iz otroštva, z 
zgubljenim in razkritim časom gospe Vrančič, z življenjem njene meščanske družine, to je tema, ki je veliko obetala. Proust je bil meščan in je opisoval meščanstvo, gospa Vrančič je bila meščanka, ki je mladost preživljala ob knjigah, slikah, na kolesu, v ljubljanski čolnarni, živela urejen vsakdanjik, kjer se je vedelo, kaj se spodobi, kaj se sme in česa se ne sme. Na srečo so bili tudi fotografski albumi gospe Vrančič urejeni in so ponujali gradivo. Film smo snemali predvsem na njenem domu.

\section{Saj res, kakšno vlogo pa ima v dokumentarnih filmih prostor?}

Prostor je pomemben, daje okvir. Mislim, da je v filmih, kot sta Gostilna in Kolizej, ki sem ga delala z Žarom Lužnikom, to prišlo do izraza. V gostilno so prihajali moški, vsak s svojo zgodbo. Teden dni sem z ekipo preživela v gostilni na Planini nad Vrhniko. V Kolizej pa so se naselili ljudje, vsak s svojo usodo, in ta stavba jih je zaznamovala. Tudi pri gospe Vrančič so prostori, njen dom, stavba univerzitetne knjižnice, pomembno določilo. Prostor v dokumentarnem filmu nosi dogajanje, nosi pomenljiv naboj.

\section{Dejali ste, da na začetku oblikovanja filmske zamisli posežete po literaturi. To je vsekakor dobra podlaga besedilu in scenariju. Kakšno vlogo pa ima glasba v doku- mentarnem filmu?}

Glasba ima pomembno funkcijo. Pri Magdalenicah najprej zaslišimo Erika Satieja Gnosienne št. 4 in 5. Skladba je jasna, umirjena, predvidljiva, kot je življenje v urejenem meščanskem domu. Arhivski posnetki Proustovega časa so tudi zahtevali ustrezno glasbeno operetno podlago iz časa, imenovanega La belle époque. Za film Prizori iz življenja pri Hlebanjevih sem prosila soproga Urbana Kodra, da napiše glasbo. Na Glasbenonarodopisnem inštitutu SAZU smo našli zvočni posnetek izpred pol stoletja, na katerem ded zdajšnjega gospodarja na Hlebanjevini prepeva a capella. Ta posnetek je Urban uporabil za osnovo, ga dopolnil z orkestracijo in $v$ tem slogu spisal tudi scensko glasbo. In potem je celo na filmskem festivalu v Portorožu za to glasbo dobil nagrado. To zgodbico povem zato, ker mislim, da mora biti glasba v dokumentarcu organska in nikoli nadomestek za naravne zvoke.

\section{Kakšen pa je vaš odnos do gledalca?}

Vedno sem imela v mislih tistega, ki bo film gledal. Meni je gledalec, ki ni neka uniformna pojava, nadvse pomemben. Vsak človek film gleda s celoto svoje osebnosti. Želja vsakega avtorja pa je, da bi stvari naredil tako dobro, da bi ga gledalec razumel, da bi vedel, kaj je hotel povedati. Meni, denimo, je veliko pomenila pripomba slovenskega kiparja Mirsada Begića, rekdobesednega, a natančnega opazovalca življenja ... »Sem takoj vedel, da je to tvoj film. «Prepoznal je način in tisto, kar sem želela povedati. Sicer pa: film ne obstaja, dokler ga ne vidijo ljudje. 